\title{
CARBAMAZEPINE KINETICS IN CARDIAC PATIENTS BEFORE AND DURING AMIODARONE
}

\author{
SILMARA A. O. LEITE*, PAULO J.M. LEITE*, GILBERTO A. ROCHA**, PHILIP A. ROUTLEDGE***, \\ PAULO ROGÉRIO M. BITTENCOURT*
}

SUMMARY - Carbamazepine and amiodarone may often be used together, especially in countries where cardiomyopathies are common. In this study single doses of carbamazepine $(400 \mathrm{mg}$ ) were given to patients with cardiac disease before and after one month of therapy with amiodarone, $400 \mathrm{mg}$ daily. The kinetic profile of carbamazepine, its free fraction, and serum amiodarone, were measured at the two occasions. There was no statistically significant change in carbamazepine kinetics or free fraction, before and after the introduction of amiodarone. The concentrations of amidarone after one month of therapy were low. It is sugested that the possible interaction in the hepatic metabolism was not demonstrated because amiodarone concentrations were not enough to inhibit carbamazepine metabolism.

KEY WORDS: amiodarone, carbamazepine, epilepsy, antiepileptic drugs, arrythmia.

\section{Cinética da carbamazepina em pacientes cardíacos antes e durante amiodarona}

Carbamazepina e amiodarona podem frequentemente ser usadas em conjunto, especialmente em países em que as cardiomiopatias são comuns. Neste estudo doses de carbamazepina $(400 \mathrm{mg})$ foram administradas a pacientes com doenças cardíacas antes e depois de um mês de terapia com amiodarona, $400 \mathrm{mg}$ ao dia. $O$ perfil cinético da carbamazepina, sua fração livre e o nível sérico da amiodarona, foram avaliados nas duas ocasiōes. Não foram observadas diferenças estatísticamente significantes na cinética da carbamazepina ou mesmo em sua fração livre, antes e depois da introdução da amiodarona. A concentração da amiodarona após um mês de terapia foi baixa. Conclui-se que a possível interação no metabolismo hepático não foi demonstrada devido as baixas concentrações de amiodarona, que provavelmente tenham sido insuficientes para inibir o metabolismo da carbamazepina.

PALAVRAS CHAVE: amiodarona, carbamazepina, drogas antiepilépticas, arritmias.

Amiodarone is a widely used antiarrhythmic agent for the treatment of resistant supraventricular and ventricular arrhythmias. Carbamazepine is a widely used antiepileptic compound, wich is metabolised by the cytochrome $\mathrm{P} 450$ system. Its metabolism may be impaired by drugs such as cimetidine ${ }^{8}$. Some patients have shown unexpected carbamazepine toxicity during amiodarone therapy, and the dosage necessary to produce clinical toxicity decreased with time after onset of therapy (Bittencourt, unpublished data personal experience). An interaction between the two drugs could be due to inhibition of liver metabolism, as predicted from other amiodarone interactions, such as with warfarin ${ }^{19}$. Between 0.5 and $2 \%$ of the Brazilian population have epilepsy and a possible indication for carbamazepine ${ }^{3}$. Central and South American trypanosomiasis, also called "Chagas' disease", is a common cause of ventricular and supraventricular arrhythmias which may be treated with amiodarone ${ }^{4}$. The concomitant utilization of amiodarone and carbamazepine may thus take place in these patients.

Serviços de Neurologia (*) e Cardiologia (**), Hospital Nossa Senhora das Graças, Curitiba, Brasil e Departamento de Farmacologia e Terapêutica (***), Universidade de País de Gales, Faculdade de Medicina, Heath Park, Cardiff, País de Gales. Aceite: 4-novembro-1993. 
The present study was designed to investigate this interaction and to exclude the possibility of other interactions at the levels of absorption, plasma protein-binding, and at the brain.

\section{MATERIAL AND METHODS}

The study was prospective and controlled, each patient serving as its own control. The ethic principles of clinical investigation specified in the Helsinki declaration and its ammendments were followed.

Five men and four women aged between 38 and 70 years $(58.4 \pm 8.94$, mean \pm standard deviation) were included on the study. Their weight varied between $58-79 \mathrm{~kg}$ (mean $=69.7 \mathrm{~kg}$ ). Two patients suffered of Chagas' disease, and the rest had ischaemic cardiomyopathy-related arrythmias. In 6 cases this was premature ventricular contractions; in two cases it was high frequency supraventricular tachycardia and one patient has sinus arrythmia. Patients were admitted to hospital before and one month after starting therapy with amiodarone ( $200 \mathrm{mg}$, orally). The dose of carbamazepine ( $400 \mathrm{mg}$, orally) was given 72 hours before amiodarone in the first admission and between 8 and 12 hours after amiodarone on the second. Patients did not change their therapeutic regimens while taking part in the study. Throughout the study they received amiodarone $200 \mathrm{mg}$ orally every 12 hours. On the two occasions they received a single dose of carbamazepine ( $400 \mathrm{mg}$, orally), and blood samples were collected before and $1,2,4,6,8,12,24,48$ and 72 hours after administration.

After centrifugation serum samples were kept at $-20^{\circ} \mathrm{C}$ until determination of serum concentration of carbamazepine and amiodarone by high performance liquid chromatography ${ }^{1}$. Area under the curve in the time $\mathbf{X}$ concentration graph of carbamazepine was measured using the linear trapezoidal rule. Statistical significance was tested using paired Student's $t$-test with $p<0.05$ being the minimum level of statistical significance. Plasma protein binding was determined by equilibrium dialysis at $\mathrm{pH} 7.4$ and $37^{\circ} \mathrm{C}$ using trace amounts of $14^{\circ} \mathrm{C}$ carbamazepine on at least four of the plasma samples collected on each occasion. Serum concentrations of amiodarone/des-ethylamiodarone were determined by high performance liquid chromatography ${ }^{11}$.

Patients were fully examined and investigated during both admissions. Between 4 and 8 hours after the administration of carbamazepine patients were examined for signs and symptoms of toxicity such as dizziness, nausea, somnolence, diplopia, ataxia, tremor, vertical and horizontal nystagmus, smooth pursuit eye movements. These findings were quantified as absent, discrete, moderate or severe ${ }^{6}$.

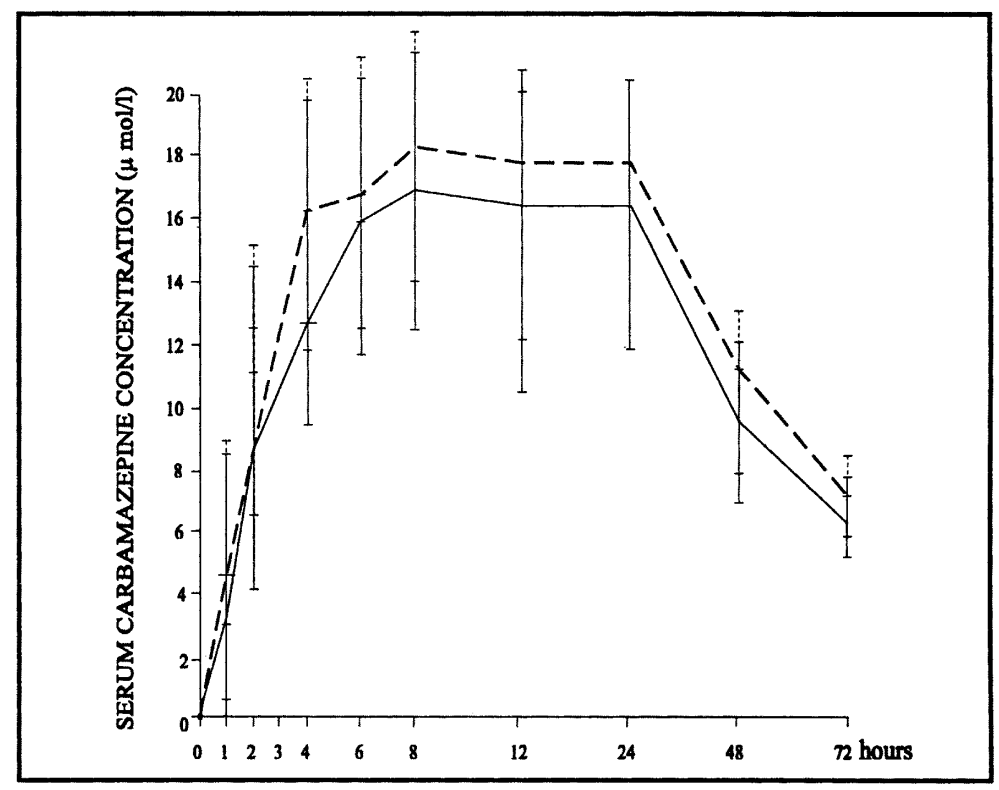

Fig 1. Time course of the serum concentrations of carbamazepine (umoll) after a single orcl dose of $400 \mathrm{mg}$, in 9 patients with cardiac disease, before (full line) and one month after (dotted line) therapy with amiodarone. 
Table 1. Area under the curve (AUC) and constant of elimination (K) of carbamazepine before and after one month therapy with amiodarone in 9 subjects with cardiac disease.

\begin{tabular}{|c|c|c|c|c|c|}
\hline \multicolumn{3}{|c|}{ Before Amiodarone } & \multicolumn{3}{|c|}{ During Amiodarone } \\
\hline Patient & $\begin{array}{c}\text { AUC } \\
\text { (umol/1.h) }\end{array}$ & $\begin{array}{c}\mathrm{K} \\
\left(\mathbf{H}^{-1}\right)\end{array}$ & Patient & $\begin{array}{c}\text { AUC } \\
\text { (umol/1.h }\end{array}$ & $\begin{array}{c}\mathbf{K} \\
\left(\mathbf{H}^{-1}\right)\end{array}$ \\
\hline 1 & 1732.0 & .0159 & 1 & 0263.0 & .0159 \\
\hline 2 & 1218.3 & .0253 & 2 & 1015.5 & .0253 \\
\hline 3 & 2145.3 & .0228 & 3 & 1274.1 & .0228 \\
\hline 4 & 2164.4 & .0177 & 4 & 2383.4 & .0144 \\
\hline 5 & 1429.5 & .0299 & 5 & 1704.7 & .0197 \\
\hline 6 & 1041.1 & .0242 & 6 & 1221.3 & .0164 \\
\hline 7 & 1434.2 & .0278 & 7 & 1819.2 & .0155 \\
\hline 8 & 1739.6 & .0149 & 8 & 1366.3 & .0179 \\
\hline 9 & 21203.0 & .0180 & 9 & 1390.6 & .0310 \\
\hline Mean & 1667.5 & - & Mean & 1615.3 & - \\
\hline $\begin{array}{l}\text { Standard } \\
\text { Deviation }\end{array}$ & 415.2 & - & $\begin{array}{l}\text { Standard } \\
\text { Deviation }\end{array}$ & 492.8 & - \\
\hline
\end{tabular}

\section{RESULTS}

Figure 1 shows results of total carbamazepine concentrations in the 9 patients before and during amiodarone ( $200 \mathrm{mg}$, orally). The rate of absorption was relatively slow with a time to peak of $9.0 \pm 6.6$ (mean $\pm \mathrm{sd}$ ) $\mathrm{h}$ before and $7.3 \pm 2.4 \mathrm{~h}$, during amiodarone therapy. Table 1 shows areas under the curve and $\mathrm{k}$ elimination constants of carbamazepine before and during amiodarone. Table 2 shows the free fractions of carbamazepine before and after one month of amiodarone therapy. Serum concentrations of amiodarone and its metabolite are shown on Table 3. There were no signs of toxicity before and until 8 hours after administration of carbamazepine in either admission. Clinical, laboratory and radiological investigations (chest X-ray, ECG, full blood count, ESR, creatinine, blood sugar) did not show significant changes except in arrhythmias between the two admissions. Area under the curve for carbamazepine given alone was $1667.5 \pm 415.2$ (mean \pm standard deviation) umol//h. Therapeutic concentrations were reached in patients 4,5 and 9 . Patient 9 had therapeutic serum concentrations for 24 hours. The plateau of serum concentrations between 12 and 24 hours $(15.9 \pm 5.2$ umol/, mean \pm standard deviation) was relatively low, and 72 hours after administration carbamazepine was still present in the blood. Terminal half-life elimination was $34 \pm 8 \mathrm{~h}$ before and $37 \pm 9 \mathrm{~h}$ during amiodarone therapy. The free fraction of carbamazepine was $0.325 \pm 0.035$ before and $0.323 \pm 0.040$ after treatment with amiodarone.

AUC during amiodarone was $1615.3 \pm 492.8$ (mean $\pm \mathrm{sd}$ ) umol//h. There was no significant change compared to before amiodarone $(p>0.05)$. Therapeutic serum concentrations were reached in the same 3 patients as before but also by Patient 3 during amiodarone therapy. The plateau of serum concentrations was approximately 18 umol/l (mean) between 12 and 24 hours after administration.

\section{COMMENTS}

Although amiodarone has been used as an antiarrhythmic agent for over a decade knowledge about its kinetics is recent and incomplete ${ }^{14}$. It is slowly absorbed, with a peak serum concentration between 4 and 5 hours after oral administration. The bioavailability is low in view of the dissolution at the intestinal mucosa. In the circulation it is highly bound to proteins. Limits of "therapeutic" serum concentrations are difficult to determine. The lower limit has been estimated at the levels where there is recurrence of arrhythmia after amiodarone withdrawal, between 0.5 and $1.0 \mathrm{ug} / \mathrm{ml}$. Maximum therapeutic concentrations are unknown because months may elapse after the concentrations have reached a plateau and side-effects appear. Amiodarone leaves plasma rapidly and distributes throughout body tissues, mainly liver, lungs, heart and fat ${ }^{10}$. Only after equilibrium antiarrhythmic effect is seen, between 10 and 60 days after oral maintenance doses. When a quicker 
Table 2. Free fractions of carbamazepine (CBZ) before and during amiodarone therapy in 9 patients with cardiac disease.

\begin{tabular}{|c|c|c|c|c|c|c|}
\hline \multirow[t]{2}{*}{ Patient } & \multicolumn{3}{|c|}{$\begin{array}{l}\text { CBZ-free fraction } \\
\text { CBZ alone }\end{array}$} & \multicolumn{3}{|c|}{$\begin{array}{l}\text { CBZ-free fraction } \\
\text { CBZ+amiodarone }\end{array}$} \\
\hline & mean & sd & median & mean & sd & median \\
\hline 1 & 0.35 & 6.38 & 0.35 & 0.35 & 5.78 & 0.35 \\
\hline 2 & 0.33 & 0.08 & 0.33 & 0.29 & 1.89 & 0.29 \\
\hline 3 & 0.38 & 7.70 & 0.35 & 0.35 & 2.44 & 0.34 \\
\hline 4 & 0.34 & 1.72 & 0.35 & 0.36 & 3.61 & 0.63 \\
\hline 5 & 0.26 & 4.61 & 0.26 & 0.25 & 2.53 & 0.24 \\
\hline 6 & 0.31 & 9.10 & 0.36 & 0.30 & 3.47 & 0.30 \\
\hline 7 & 0.31 & 4.21 & 0.30 & 0.28 & 2.11 & 0.28 \\
\hline 8 & 0.34 & 2.87 & 0.36 & 0.37 & 3.39 & 0.36 \\
\hline 9 & 0.33 & 1.96 & 0.34 & 0.32 & 4.46 & 0.33 \\
\hline
\end{tabular}

sd, standard deviation.

effect is needed it is important to start with loading doses. Plasma concentrations after oral administration are erratic until at least 4 or 6 weeks after maintenance or loading doses ${ }^{18}$. Elimination

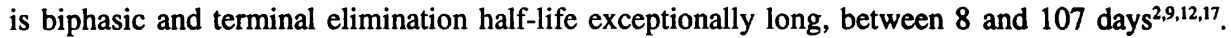
Amiodarone is metabolized predominantly in the liver. There are two well-known metabolites, dides-ethyl-amiodarone and des-ethyl-amiodarone, the latter found in man, although its clinical activity is unknown. During long-term therapy concentration of des-ethyl-amiodarone is one or two times greater than that of amiodarone. The relationship of the plasma concentration of des-ethylamiodarone/amiodarone is useful to evaluate compliance to short term therapy ${ }^{10}$. The side-effects of amiodarone appear mostly during chronic treatment and involve the cardiac, neurologic, and ocular systems, the skin and thyroid gland.

Carbamazepine is used for epileptic disorders, trigeminal and other neuralgias and for some psychiatric disturbances. Its absorption after oral administration is slow ${ }^{17}$ and serum concentrations fluctuate widely during absorption, probably in relation to slow dissolution in the gastrointestinal fluid and in relation to its anticholinergic action during chronic treatment, which slows the time of gastrointestinal transit ${ }^{18}$. Peak plasma or serum concentrations are reached between 4 and 8 hours after ingestion, but later peaks between 24 and 32 hours have been reported. The relationship between oral dose and serum concentrations has been shown to be linear in some instances, and

Table 3. Serum levels of amiodarone $(A M) /$ des-ethylamiodarone (DEA) (umoLll) in 9 patients with cardiac disease after one month therapy with amiodarone.

\begin{tabular}{cc}
\hline Patient & AM/DEA \\
\hline 1 & $0.55 / 0.98$ \\
2 & $0.64 / 0.72$ \\
3 & $0.26 / 0.69$ \\
4 & $0.21 / 0.52$ \\
5 & $0.42 / 0.76$ \\
6 & $0.48 / 0.58$ \\
7 & $0.51 / 1.37$ \\
8 & $0.90 / 1.55$ \\
9 & $0.36 / 0.36$ \\
\hline
\end{tabular}
nonlinear in others ${ }^{16}$. Bittencourt and Richens ${ }^{6}$ demonstrated a linear relationship between serum concentration and effect on saccadic eye movements, but not between serum concentrations and the slower smooth pursuit eye movements, eventhough both were significantly impaired in healthy subjects after a single dose ${ }^{6}$. In the circulation $75 \%$ is bound to plasma proteins. Carbamazepine induces an increase in quantity of cytochrome $\mathrm{p}-450$ during long-term therapy decreasing the plateau serum concentrations, the phenomenon known as auto-induction. In healthy subjects the half-life varies between 18 and 55 hours and total clearance between 0.0011 and $0.0210 \mathrm{1} / \mathrm{kg} / \mathrm{h}$ after a single dose ${ }^{15}$. Side-effects are frequent 
and usually not severe. They include somnolence, ataxia, dizziness, nystagmus, diplopia, slurred speech and headache ${ }^{5}$.

When the results of the present study are compared to those of comparable studies it may be noticed that absorption of carbamazepine is slower in middle aged cardiac patients than in healthy young individuals, aged $25 \pm 4.2$ years $^{7}$, who after an oral dose of $400 \mathrm{mg}$ developed serum concentrations respectively of $8.5,15.3,18.1,21.5$ and $19.6 \mathrm{umol} / 1$ at $1,2,4,6$ and 8 hours. When these results, observed after doses of $400 \mathrm{mg}$, are compared to those observed after a single oral dose of $600 \mathrm{mg}^{13}$ given to neurological inpatients aged $40 \pm 19.3$ years, it may be noticed that the greater oral dose produces therapeutic serum concentrations at 4 hours $(22.3$ umol/l), which continue rising at $6 \mathrm{hours}(27.3 \mathrm{umol} / \mathrm{l})$ and at 8 hours $(31.5 \mathrm{umol} / 1$, means). These findings are generally in disagreement with pharmacokinetic concepts that at the extremes of age the possibility of toxicity is greater. Few studies of carbmazepine kinectics in cardiac or elderly patients have been carried out ${ }^{15}$.

An absorption interaction between amiodarone and carbamazepine is difficult to be predicted since amiodarone undergoes desalkilation in the intestinal mucosa while carbamazepine undergoes a slow dissolution in gastrointestinal fluids. An interaction at plasma protein binding sites can be ruled out by the present results, but it might have been an alternative explanation for the initial clinical observation that led to the study.

Holt and colleagues ${ }^{10}$ described the iiver metabolism of amiodarone and Watt and colleagues ${ }^{19}$ demonstrated its interaction with warfarin at the liver. Warfarin is also metabolized at the cytochrome oxidase p-450 enzymatic system. The interaction with warfarin was demonstrated with amiodarone concentrations of $2.57 \pm 1.73 \mathrm{umol} / 1$ and with des-ethyl amiodarone concentrations in the plasma of $1.07 \pm 0.32 \mathrm{umol} / 1$. Levels found in the 9 patients of the present study were all below $0.65 \mathrm{umol} / 1$ for amiodarone and 7 of the 9 patients had des-ethyl amiodarone concentrations below $1.0 \mathrm{umol} / 1$, while the other 2 had respectively 1.37 and $1.55 \mathrm{umol} / \mathrm{l}$.

We would like to put forward the hypothesis that an interaction at the hepatic metabolism between amiodarone and carbamazepine was not demonstrated in this study because amiodarone serum concentrations were not sufficient to inhibit the metabolism of carbamazepine. In order for this interaction to be properly demonstrated we suggest that the dosage regimen of Siddoway and colleagues $^{18}$ be followed. In this scheme, $2000 \mathrm{mg}$ amiodarone should be given to adults on the first day, $1400 \mathrm{mg}$ daily over the second, third and fourth days, followed by $1000 \mathrm{mg}$ daily for a week, $800 \mathrm{mg}$ daily for 2 weeks, and $600 \mathrm{mg}$ daily for 4 weeks. After this time, maintenance could be kept with $400 \mathrm{mg}$ or $600 \mathrm{mg}$ daily. The possibility that severe side-effects may occurr at this dose should be kept in mind.

Acknowledgement - The authors would like to thank nursing staff at Hospital N.S. das Graças in Curitiba for their cooperation, and Ms Maristela G. Calderari and Ms Marli Osna for word processing. The study was supported by an internal grants of the Unidade de Neurologia Clínica S/C, Curitiba and of the Department of Pharmacology and Therapeutics, University of Wales College of Medicine.

\section{REFERENCES}

1. Adams RF, Vandermark FL. Simultaneous high pressure liquid chromatrographic determination of some anticonvulsivants in serum. Clin Chem 1976, 22:25-31.

2. Andreasen F, Agerback H, Byerregaard P, Gotzche H. Pharmacokinetics of amiodarone after intravenous and oral administration. J Clin Pharmacol 1981, 19:293-299.

3. Bittencourt PRM. Epilepsy in Latin America. In Laidlaw J, Richens A, Oxley J (eds). Textbook of epilepsy. Edinburgh: Churchill-Livingstone 1988, p 518-528.

4. Bittencourt PRM, Gracia CM, Lorenzana P. Epilepsy and parasitosis of the central nervous system. In Pedley T, Meldrum B (eds). Recent advances in epilepsy, Vol 4. Edinburgh: Churchill-Livingstone, 1988, p 123-161.

5. Bittencourt PRM, Perucca E, Crema A. Cerebellar toxicity of antiepileptic drugs. In Blum K, Manzo L (eds). Neurotoxicology, drug and chemical toxicology. London: Marcel Dekker, 1985, p 233-250. 
6. Bittencourt PRM, Richens A. Assessment of antiepileptic drug toxicity by eye movements. In Buser PA, Cobb WA, Okuma T (eds). Kyoto Symposia (EEG Suppl 36). Amsterdam: Elsevier, 1982, p.467-481.

7. Bittencourt PRM, Richens A. Concentrações séricas eficazes após doses únicas de drogas antiepilépticas: conceito de dose-carga. Arq Neuropsiquiatr, 1985, 43:11-16.

8. Dalton MJ, Powell JR. Messenheimer JA Jr. The influence of cimetidine on single dose carbamazepine pharmacokinetics. Epilepsia 1985, 26 (Suppl):127-130.

9. Haffajee CL, Love JC, Canda AT, Lesko LJ, Asdourian G, Alpert JS. Clinical pharmacokinetics and efficacy of amiodarone for refractory tachyarrhythmias. Circulation 1983, 67:1347-1355.

10. Holt WD, Tucker GT, Jackson PR, Story GCA. Amiodarone pharmacokinetics. Am Heart J, 1983, 106:840-847. 11. Hutchings A, Spragg B, Routledge PA. High performance liquid chromatographic assay of amiodarone and desethylamiodarone in plasma. J Chromatogr, 1986, 382:389-393.

12. Latini R, Tognoni G, Kates RE. Clinical pharmacokinetics of amiodarone. Clin Pharmacokin 1984, 9:136-156. 13. Leite PJM, Tsanaclis LM, Markourakis T, Bittencourt PRM. Dose carga de carbamazepina e difenil-hidantoína: Utilização em pacientes de alto risco. Arq Neuropsiquiatr 1987, 45:281-287.

14. Mason WJ. Drug therapy: amiodarone. N Eng J Med 1987, 19:455-465.

15. Morselli PL. Carbamazepine: absorption, distribution and excretion. In Levy RH, Dreifuss FE, Mattson RH, Meldrum BS, Penry JK (eds). Antiepileptic drugs. Ed 3. New York: Raven Press 1989, p 473-491.

16. Perucca E, Bittencourt PRM, Richens A. Effect of dose increments on serum carbamazepine concentration in epileptic patients. Clin Pharmacokin 1980, 5:576-582.

17. Plomp TA, van Rossum JM, van Lie T, Maes RAA. Pharmacokinetics and body distribution of amiodarone in man. Arzneimittelforsch 1984, 34:513-520.

18. Siddoway AL, McAllister CB, Wilkinson GR, Roden DM, Woosley RL. Amiodarone dosing: a proposal based on its pharmacokinetics. Am Heart J 1983, 106:951-956.

19. Watt AH. Stephens MR, Buss DC, Routledge PA. Amiodarone reduces plasma warfarin clearance in man. $\mathrm{Br} J$ Clin Pharmacol 1985, 20:707-709. 